\title{
Law Enforcement to the Negligent Entrepreneurs in Accomplishing Mining Reclamation in order to be Efficient according to its Function
}

\author{
Mimin Mintarsih \\ Faculty of Law \\ Islamic University of Jakarta \\ Jakarta, Indonesia \\ miminmintarsih@uid.ac.id
}

\author{
Mudzakir Iskandar \\ Faculty of Law \\ Islamic University of Jakarta \\ Jakarta, Indonesia \\ muda_huk@yahoo.com
}

\author{
Bambang Sukamto \\ Faculty of Law \\ Islamic University of Jakarta \\ Jakarta, Indonesia \\ setauid@gmail.com
}

\begin{abstract}
Mining goods are assets owned by Indonesia that can be added value in improving people's prosperity. As the mandate in the 1945 Constitution, Article 33 paragraph 3 states: "The earth, water and natural resources contained therein are controlled by the state and used for the greatest prosperity of the people". One of the elements to realize the prosperity and prosperity of the people in the management of the mine sector must reach the optimal level. Vice versa. If the management is unprofessional and not optimal, mining management will miserable the people. One example of mining activities that are not optimal like the former mining that leaves the neglected big holes, which is very dangerous to human life and other living creatures. It is, therefore, necessary to have a firm and consistent law enforcement that can create a deterrent effect. The purpose of this study is to analyze law enforcement efforts against neglected entrepreneurs in accomplishing mining reclamation, with empirical juridical method. The result reveals that the entrepreneur has an obligation to complete the mining reclamation in order to be efficient in accordance with its allocation. It is regulated in Law no. 4 of 2009 About Mineral and Coal Mining Article 96 point c. And accomplishing efforts are not done, then the sanctions will be given in the form of administrative sanctions, namely Article 151 paragraph 1 and 2 of Law no. 4 year 2009.
\end{abstract}

Keywords - law enforcement, negligent businessman, mining reclamation

\section{INTRODUCTION}

\section{A. Background}

Indonesia is a country with abundant natural resources. It can be expressed a sentence Gemah Ripah Loh Jinawi which has an extraordinary meaning, namely wealth that will bring prosperity, tranquility, welfare and peace for the people of Indonesia as a whole.

Indonesia should feel grateful for the natural resources provided by the Almighty Allah SWT. Besides, it is the mandate of the 1945 Constitution Article 33 paragraph 3 states: "The earth, the water and the natural wealth contained therein are controlled by the state and used for the greatest prosperity of the people".

Various kinds of natural resources owned, such as mining materials become one of the largest assets owned by Indonesia. No wonder Indonesia become one of the countries with the potential of mining with the largest land in the world. The extent of land with the potential of mining properties is spread throughout the country, where its existence needs to be explored more deeply so that the results can be utilized for the welfare of the Indonesian people. Positive and negative impacts can be generated from mining activities done by mining entrepreneurs. Although negative impacts are more dominant as a result of exploitation of mining activities that is inconsistent with the rules or designations. Most problems arise after mining activities are completed. These problems may include environmental degradation, physical and chemical da mage to the soil, and the extinction of several flora-fauna scattered within the former mine site.

The mining industry in Indonesia is considered to be the backbone of the country's economy. This is because, every mining activity carried out always make a significant contribution as Non-Tax Revenue (PNBP). Given the magnitude of the potential benefits generated from mining activities, the problems caused by mining activities can be completed without causing negative impacts that harm the community much less to endanger the lives of humans and other living creatures.

One of the mining issues is Post-Mine Land Reclamation. In mining activities, reclamation becomes a mandatory requirement. Reclamation is an activity undertaken throughout the mining business stages to organize, restore and improve the quality of the environment and ecosystem in order to function again in accordance with its allocation. It is regulated in Law no. 4 of 2009 Chapter I General Provisions, Article 1. Reclamation is an activity aimed at improving or managing the use of disturbed land as a result of mining business activities, in order to be functional and efficient in accordance with its allocation. Environmental-oriented development becomes an important requirement for every nation and country that wants the sustainability of natural resources. The wealth possessed by Indonesia, will bring prosperity, peace, prosperity and peace to the people as a whole. Therefore, natural resources need to be maintained and maintained for the survival of hu man life now, as well as for future generations [1].

Considering that the entrepreneur is negligent in carrying out mining reclamation in order to be effective in the 
allocation, therefore law enforce ment is needed which will make the deterrent effect, considering the impact.

Based on these backgrounds, it is necessary to examine the law enforcement against negligent entrepreneurs in carrying out mining reclamation, in the hope of producing a firmer regulation, and bringing a deterrent effect. The main problem in the research is how law enforcement against negligent entrepreneurs in accomplishing mining reclamation?

\section{B. Research Objectives}

The objective of the research is to analyze law enforcement against negligent entrepreneurs in carrying out mining reclamation.

\section{Research Methods}

The research method used was empirical juridical method. It was done by sorting the most important data from several journals. Data collection was done through literature studies obtained from several journals and books, as well as adjusting the latest data on site conditions. Techniques of data collection used comparative analysis method by comparing various journals and other literature.

\section{DISCUSSION}

\section{A. Law Enforcement}

Sudarto [2], gave the meaning of law enforcement, it is the concern and cultivation, both unlawful acts that really happen (onrecht in actu) and the unlawful act that may happen (onrecht in potentie).

Law enforcement is a series of process of elaboration of ideas and ideals that contain moral values such as justice and truth into concrete forms, in realizing it requires an organization such as police, prosecutors, courts and correctional institutions as a classical element of law enforcement established by the state, in other words that law enforcement essentially contains supremacy of substantial value that is justice. [3].

According to Soerjono Soekanto [4] there are several factors that influence the enforcement of the law itself, namely; 1). The legal factor is the Act. 2). Law enforcement factors, ie the parties that make up and apply the law, 3). Factor means or facilities that support law enforcement. 4). The societal factor, ie the environment in which the law is applicable or applied. 5). Cultural factors, namely as a result of work, inventiveness, and taste based on human initiative in the social life.

\section{B. Mining Reclamation}

Mining activities basically have many negative impacts, especially on environ mental conditions that cannot be reused properly. Reclamation is an activity aimed at improving or managing the use of disturbed land as a result of mining business activities, in order to be functional and efficient according to its allocation. Environmental-oriented development becomes an important requirement for every nation and country that wants the sustainability of natural resources. Therefore, natural resources need to be maintained and maintained for the survival of human life now, as well as for future generations [1].
In Law No. 4 year 2009 Article 96 and Perpu. 78 year 2010 Article 2 paragraph 1 about Post-Mining Reclamation, the former mining land reclamation program explains that the mine reclamation obligation is a mandatory program that must be done by every private and non-private company. In addition to the regulation in the law, it can also be found in the Minister of Forestry Regulation no. P.4/Menhut-II/2011 concerning Guidelines for Reclamation of Former Mining in Forest Areas, every mining and Energy Company has an obligation to carry out mine land reclamation of borrowed-use forest areas (Ministry of Forestry, 2012). It aims to restore the condition of former mining area or damaged forest area as the impact of mining activity so that the former mining land in question can function again in accordance with its designation.

The other regulations governing the mining company's obligations to recover the former mining areas are as follows:

1. Article 30 of Law Number 11 Year 1967 concerning Basic Provisions on Mining:

In case of completion of mining of excavated material at a work place, the holder of the Mining Concession shall be required to return the land in such a way that it does not pose any danger to the surrounding community.

2. Article 46 paragraph (4) and (5) of Government Regulation Number 75 of 2001 concerning Second Amendment to Government Regulation Number 32 Year 1969:

"Before leaving the former Mining Authority, either due to cancellation or otherwise, the holder of the Mining Authority shall first undertake safeguards against the objects and buildings and the circumstances surrounding the land which may endanger public safety."

3. Government Regulation Number 78 of 2010 on PostMining Reclamation in Article 6:

"Holders of IUP (Mining Business Licenses) Exploration and IUPK (Special Mining Business Licenses) Exploration that has completed the feasibility study activity shall apply for approval of the reclamation plan and post- to the Minister, Governor, or Regent/Mayor in accordance with their authority". In accordance with the provisions of the Post-mining reclamation plan should be prepared based on environmental documents that have been approved by the competent authority in accordance with the provisions of environmental protection and management.

\section{Law Enforcement Analysis Against Negligent Businessmen in Mining Reclamation}

How much of the natural wealth is the Allah SWT. gives to the Unitary State of the Republic of Indonesia. So that the natural wealth such as mining goods can be used as assets owned by Indonesia and can be added value in improving the prosperity of its people. As the mandate of the 1945 Constitution, Article 33 paragraph 3 states: "The earth, water and natural resources contained therein are controlled by the state and used for the greatest prosperity of the people". One of the elements to realize the prosperity and welfare of the people is in the management of the mine must reach the optimal level, and vice versa. If the management of mines is not professional and optimal it will harm the people. One example of not optimal mining activities are such as ex- 
mining that leaves large holes that are neglected, which is very dangerous to human life and other living creatures. It is, therefore, necessary to have a firm and consistent law enforcement that can create a deterrent effect.

Sudarto [2], gave the meaning of law enforcement is the concern and cultivation, both unlawful acts that really happen (onrecht in actu) and the unlawful act that may happen (onrecht in potentie).

Law enforcement is a series of process of elaboration of ideas and ideals that contain moral values such as justice and truth into concrete forms, in realizing it requires an organization such as police, prosecutors, courts and correctional institutions as a classical element of law enforcement established by the state, in other words that law enforcement essentially contains supremacy of substantial value that is justice. [3]

The five factors that influence law enforcement according to Soerjono Soekanto can be linked to issues concerning law enforcement of mining reclamation which can be analyzed by as follows:

1) The legal factor itself, namely the Law. In Law No. 4 of 2009 on Mineral and Coal Mining has been described in detail about the rules that need to be implemented in running the mining business, in the regulations are also mentioned on the obligations that need to be done mining entrepreneurs. One of them is the obligation to reclaim the mine in accordance with its designation.

2) Law enforcement factors. In Big Indonesian Dictionary (1998: 912), the enforcer is the one who establishes, upholds. Law enforcers are the ones enforcing the law, consisting of Police, Prosecutors, Judges and Lawyers as well as Penitentiaries. Thus, law enforcers should play a more active, cooperative and synergic role with other law enforcement. In performing their respective functions so as to provide a deterrent effect on the mine entrepreneurs who neglect in carrying out their oblig ations.

3) Factors of facilities or infrastructure that support law enforcement in the implementation of post-mining land reclamation. The support of such facilities includes several matters, including: funds supporting mining reclamation activities, experts skilled in the field of mine site processing infrastructure, adequate equipment, etc.

4) Community factors. In essence law enforcement comes from the community to achieve justice and welfare of the community. Thus, in a certain perspective the public can be a determinant of the success of a law enforcement process. With regard to mine reclamation, community contributions are required by assisting those responsible for managing post-mining land that has been reclaimed to continue to be a viable and usable land in accordance with its designation.

5) Factors of culture that is as a result of work, inventiveness, and taste based on human initiative in the social life.

In law enforcement terms contained the meaning of how the law should be done. And in its application there are elements that need to be considered for the purpose of law can be reached fully, that is element of legal certainty, expediency and justice. [5] to achieve a legal certainty, there is certainty about what is allowed and what should not be done by members of the community.

Justice is the balance between the worth for all parties, either in the form of profit or in the form of loss. As for its practical language, justice can be interpreted as giving equal rights to a person's capacity or enforcement to each person proportionally, but it can also mean giving everyone equal to what his rights are based on the principle of equilibrium. Therefore, law without justice has no meaning at all. The use of the law should be noted because everyone expects the benefits in the implementation of law enforcement. Because when talking about the law, most tend to only look at the legislation, which sometimes the rule does not refer to the needs of the community.

From the description, it can be drawn the conclusion that which should be prioritized first is the element of justice, benefit and legal certainty. Ideally, every time a law is issued by law enforcement, it should contain all three elements of the legal value so that it can be realized together. But if it is not possible to be done together, then it should be prioritized the three elements in accordance with the priority order of justice, benefit and legal certainty. Thus, in law enforcement efforts against negligent entrepreneurs in carrying out their mining reclamation, it needs to apply the three elements that underlie the achievement of the appropriate legal objectives.

Law no. 4 of 2009 on Mineral and Coal Mining has described in detail about the rules that need to be implemented in running the mining business, in the regulations are also mentioned on the obligations that need to be done by mining entrepreneurs. One of them is the obligation to reclaim the mine in accordance with its allocation, as in Chapter XIII Rights and Obligations Article 96 point $\mathrm{c}$. And if not done, then sanctions for employers will be given. The sanction is administrative sanctions, namely Article 151 paragraph 1 and 2 of Law no. 4 year 2009, in the form of written warning, suspension, part or all of exploration activity, production operation, and permit drawing. And based on Government Regulation no. 78 Year 2010 Chapter IX Administrative Sanctions in Article 50 paragraph 2 is in the form of:

a. Written Warning

b. Suspension of activities, and / or

c. Revocation of IUP, IUPK, or IPR

Sanctions granted to mining negligent entrepreneurs in carrying out their obligations, either by law or by Government Regulation, the sanction is administrative sanction.

\section{REFERENCES}

[1] I. Arif, Perencanaan Tambang Total Sebagai Upaya Penyelesaian Persoalan Lingkungan Dunia Pertambangan. Manado: Universitas Sam Ratulangi, 2007.

[2] Sudarto, Kapita Selekta Hukum Pidana. Bandung: Sahabat Kita, 1986.

[3] S. Rahardjo, Penegakan Hukum:Suatu Tinjauan Sosiologis. Yogyakarta: Genta Publishing, 2009.

[4] S. Soekanto, Faktor-Faktor yang Mempengaruhi Penegakan Hukum. Jakarta: PT. Raja Grafindo Persada, 2011.

[5] W. Prodjodikoro, Perbuatan Melanggar Hukum Dipandang Dari Sudut Hukum Perdata. Bandung: Mandar Maju, 2000. 